\title{
Determinan Peresepan Polifarmasi pada Resep Rawat Jalan di Rumah Sakit Rujukan
}

\author{
Andriane Y, ${ }^{1}$ Sastramihardja HS, ${ }^{2}$ Ruslami $\mathbf{R}^{3}$ \\ ${ }^{1}$ Program Pascasarjana Ilmu Kedokteran Dasar Universitas Padjadjaran, ${ }^{2.3}$ Departemen Farmakologi \\ dan Terapi Fakultas Kedokteran Universitas Padjadjaran Bandung
}

\begin{abstract}
Abstrak
Resep polifarmasi ( $>5$ jenis obat/resep) berpotensi meningkatkan interaksi obat, efek samping obat, dan masalah lain. Pasien yang berobat ke rumah sakit (RS) rujukan umumnya berpenyakit kronik dengan komorbiditas dan komedikasi. Dilakukan penelitian potong silang untuk menganalisis determinan peresepan polifarmasi dari berbagai klinik rawat jalan di RS rujukan di Bandung. Analisis statistik menggunakan uji chi-square dan dihitung rasio prevalensi (RP). Selama bulan Oktober 2012 terdapat 2.548 resep dari lima poliklinik rawat jalan dengan jumlah resep polifarmasi terbanyak. Prevalensi polifarmasi adalah $32 \%$ dan median jumlah jenis obat adalah 5 (rentang: 5-11). Terdapat perbedaan karakteristik pasien dalam hal usia $\geq 60$ tahun ( $59,8 \%$ vs 44,8\%; $\mathrm{p}<0,001)$, jenis kelamin laki-laki $(57,1 \%$ vs 44,6\%; $\mathrm{p}<0,001)$, peserta Askes (73,6\% vs 56,1\%; $<<0,001)$, dan asal poliklinik: kardiovaskular $(72,1 \%$ vs 33,1\%; $\mathrm{p}<0,001)$ antara yang menerima resep polifarmasi dan tidak polifarmasi. Faktor dominan terhadap peresepan polifarmasi adalah dari poliklinik kardiovaskular (RP:8,80; IK95\%: 6,35-12,19). Faktor lain dengan risiko polifarmasi >3 kali adalah dari poliklinik geriatri (RP:6,68; IK95\%: 4,43-10,08) dan peserta Askes (RP:6,23; IK95\%: 3,49-11,12). Prevalensi polifarmasi resep gabungan beberapa poliklinik (574 pasien) lebih besar, yaitu 59,8\%. Simpulan, prevalensi peresepan polifarmasi di RS rujukan cukup tinggi, terlebih jika pasien menerima resep dari berbagai poliklinik. Determinan utama peresepan polifarmasi di RS rujukan adalah dari poliklinik kardiovaskular, poliklinik geriatri, dan peserta Askes.
\end{abstract}

Kata kunci: Determinan, polifarmasi, resep, rumah sakit rujukan

\section{Determinants for Polypharmacy Prescribing of the Prescription in the Outpatient Clinics of Referral Hospital}

\begin{abstract}
Polypharmacy prescription ( $\geq 5$ drugs in one prescription) potentially increased drug-drug interaction, side effects, and other problems. Patients who come to referral hospital usually were with chronic diseases, comorbidities and comedications. A cross sectional study was performed to analyze the determinants for polypharmacy prescription from clinics in referral hospital in Bandung. Data were analyzed using chisquare test and prevalence ratio (PR) were calculated. During October 2012, there were 2,548 prescriptions from five clinics with highest number of prescription. Prevalence of polypharmacy prescription was $32 \%$, the median number of drugs written were 5 (ranged: $5-11$ ). The characteristics of the patients showed a difference in aged $\geq 60$ years ( $59.8 \%$ vs $44.8 \%, \mathrm{p}<0.001)$, gender: males $(57.1 \%$ vs $44.6 \%, \mathrm{p}<0.001)$, had health insurrance $(73.6 \%$ vs $56.1 \%, p<0.001)$, and origin cardiovascular clinic $(72.1 \%$ vs $33.1 \%$, $\mathrm{p}<0.001$ ) between those receiving polypharmacy prescriptions and those receiving non polypharmacy prescription. The dominant factor for polypharmacy prescription was treated at cardiovascular clinic (PR:8.80, 95\%CI: 6.35-12.19), followed by treated at geriatry clinic (RP:6.68, 95\%CI: 4.43-10.08) and had health insurrance (RP:6.23, 95\%CI: 3.49-11.12). Polypharmacy of combined prescriptions (574 patients) was $59.8 \%$. In conclusions, prevalence of polypharmacy prescription in referral hospital in Bandung is high, even higher in patients received combined prescriptions. Main determinants for polypharmacy prescription in referral hospitals are being treated at cardiovascular clinic, geriatry clinic, and having health insurance.
\end{abstract}

Key words: Prescription, polypharmacy, referral hospital 


\section{Pendahuluan}

Polifarmasi (jumlah obat $\geq 5$ macam) merupakan masalah serius dalam sistem kesehatan karena meningkatkan morbiditas serta mortalitas yang amat berhubungan dengan polifarmasi yang tidak tepat. Polifarmasi akan menyebabkan mahalnya biaya kesehatan secara langsung maupun tidak langsung. ${ }^{1}$

Polifarmasi dapat mengakibatkan interaksi antarobat dan efek samping obat dan masalahmasalah yang juga berhubungan dengan obatobatan (drug-related problem=DRP) sehingga dapat mengganggu luaran klinis., ${ }^{2,3}$ Polifarmasi berkaitan dengan underprescribing, penggunaan medikasi yang tidak tepat (termasuk duplikasi terapi), dan ketidakpatuhan.4,5 Oleh karena itu, para profesional dalam bidang kesehatan harus sadar akan risiko-risiko dan mengevaluasi semua medikasi pada tiap-tiap kunjungan pasien untuk mencegah polifarmasi.

Prevalensi polifarmasi meningkat dari tahun ke tahun pada semua kelompok usia, terbesar terjadi pada kelompok usia 10-19 tahun (9,1\%), kelompok usia 60-69 tahun $(7,2 \%)$, dan usia 70-90 tahun (8,6\%). ${ }^{6}$ Penelitian terhadap suatu populasi di Brazil menunjukkan bahwa $85 \%$ usia tua memiliki sedikitnya satu penyakit kronik dan sekitar 10\%-nya memiliki sedikitnya lima macam penyakit. $^{2}$

Polifarmasi itu dapat didefinisikan sebagai penggunaan satu pengobatan untuk menangani efek-efek samping akibat pengobatan yang lain atau juga peningkatan jumlah pengobatan yang digunakan hingga mencapai 5 atau lebih jenis obat. ${ }^{2,7}$ Obat topikal dan herbal tidak termasuk dalam kriteria polifarmasi. ${ }^{2}$ Vitamin dan mineral yang dikonsumsi sesuai dengan kebutuhan juga tidak termasuk dalam pengukuran polifarmasi disebabkan karena keterlibatannya yang tidak konsisten dalam polifarmasi. ${ }^{2}$

Berbagai hal dapat menyebabkan polifarmasi terkait pasien maupun sarana kesehatan. Kondisi pasien misalnya penambahan usia, pendidikan, status kesehatan yang buruk, dan komorbiditas. Semakin tua seorang pasien akan semakin besar kemungkinan menderita penyakit kronik dan degeneratif yang umumnya tidak berdiri sendiri (komorbiditas) sehingga kemungkinannya terjadi komedikasi. Sarana kesehatan meliputi jumlah kunjungannya ke tempat pelayanan kesehatan, jaminan asuransi, dan provider yang multipel. ${ }^{5}$

Sesuai dengan tipenya, rumah sakit rujukan umumnya menerima dan juga merawat pasien yang dirujuk dari sarana pelayanan yang lebih rendah tingkatnya. Pasien dirujuk terkait dengan kondisi penyakit pasien yang lebih lanjut, dengan komplikasi, atau membutuhkan pelayanan yang lebih lanjut. $^{8}$

Tujuan penelitian ini adalah menganalisis hubungan antara determinan polifarmasi dan peresepan polifarmasi di rumah sakit rujukan.

\section{Metode}

Penelitian ini adalah penelitian deskriptif analitik dengan disain potong silang. Sumber data adalah resep-resep yang terdapat di Instalasi Farmasi Rawat Jalan sebuah RS rujukan di Bandung yang berasal dari 5 poliklinik rawat jalan selama bulan Oktober tahu 2012. Kelima poliklinik ini dipilih berdasarkan jumlah resep polifarmasi terbanyak; poliklinik tersebut adalah poliklinik kardiovaskular, geriatri, saraf, paru, dan ginjal hipertensi.

Peresepan dengan polifarmasi didefinisikan sebagai resep yang terdiri atas $\geq 5$ jenis obat. Obat topikal, herbal, vitamin, dan mineral yang dikonsumsi sesuai kebutuhan tidak termasuk ke dalam polifarmasi. Obat yang sama dengan kekuatan yang berbeda dihitung sebagai satu jenis obat. Formulasi satu obat dengan rute pemberian yang berbeda dianggap sebagai jenis berbeda. Kombinasi obat yang mengandung $>1$ zat aktif dianggap sebagai satu jenis obat.

Data demografik pasien, status asuransi, dan asal poliklinik ditampilkan secara deskriptif berupa persentase, sedangkan analisis statistik menggunakan uji chi-square serta penghitungan rasio prevalensi (RP). Nilai kebermaknaan secara statistik jika $\mathrm{p} \leq 0,05$. Analisis dengan program SPSS for windows versi 16.

Penelitian ini telah mendapat persetujuan Komite Etik Penelitian Kesehatan FKUP Bandung (No: 225/UN6.C2.1.2/KEPK/PN/2012).

\section{Hasil}

Selama bulan Oktober 2012, terdapat 2.548 resep yang berasal dari ke-5 poliklinik tersebut. Tabel 1 memperlihatkan profil pasien penerima resep, jumlah resep yang didapatkan oleh pasien berusia $<60$ tahun dibanding dengan usia $\geq 60$ tahun tidak jauh berbeda, proporsi laki-laki sama dengan perempuan. Hampir dua pertiga (62\%) mereka merupakan peserta Askes; pasien umum hanya sekitar $5 \%$. Hampir separuh resep berasal dari poliklinik kardiovaskular (Tabel 1).

Dari 2.548 resep, terdapat 816 (32\%) resep dengan polifarmasi. Usia rata-rata pasien adalah 62 tahun, 60\% berusia >60 tahun, sekitar 6 dari 10 adalah pasien laki-laki, tiga perempat merupakan peserta Askes, dan sekitar 70\% dari resep dengan polifarmasi berasal dari poliklinik kardiovaskular (Tabel 2).

Terdapat perbedaan pada proporsi pasien 
Tabel 1 Karakteristik Pasien yang Menerima Resep

\begin{tabular}{lrr}
\hline Variabel & n & \% \\
\hline $\begin{array}{lrr}\text { Usia (tahun) } \\
<60\end{array}$ & & \\
$\geq 60$ & 1.284 & 50,4 \\
& 1.264 & 49,6 \\
Jenis kelamin & & \\
$\quad$ Perempuan & 1.310 & 51,4 \\
Laki-laki & 1.238 & 48,6 \\
& & \\
Status asuransi & & \\
Askes & 1.573 & 61,7 \\
Jamkesmas & 410 & 16,1 \\
Gakinda & 353 & 13,9 \\
Umum & 144 & 5,6 \\
Lain-lain* & 68 & 2,7 \\
& & \\
Asal poliklinik & & \\
Kardiovaskular & 1.163 & 45,6 \\
Saraf & 538 & 21,1 \\
Ginjal hipertensi & 442 & 17,4 \\
$\quad$ Geriatri & 206 & 8,1 \\
Paru & 199 & 7,8 \\
\hline$\quad$ Jumlah & 2.548 & 100 \\
\hline Keterangan: *lain-lain=Jamsostek, kontraktor
\end{tabular}

apabila dikelompokkan berdasarkan usia $(\geq 60$ tahun). Proporsi kelompok pasien dengan usia $>60$ tahun yang menerima resep polifarmasi lebih besar bila dibanding dengan yang tidak menerima resep polifarmasi $(59,8 \%$ vs $44,8 \%$; $\mathrm{p}<0,001)$. Demikian juga dengan jenis kelamin, proporsi pasien laki-laki yang menerima resep polifarmasi lebih besar dibanding dengan yang tidak menerima resep polifarmasi $(57,1 \%$ vs 44,6\%; $\mathrm{p}<0,001)$. Jika dilihat status asuransi, proporsi pasien peserta Askes yang menerima resep polifarmasi lebih besar dibanding dengan yang tidak menerima resep polifarmasi $(73,6 \%$ vs $56,1 \%, \mathrm{p}<0,001)$. Asal dari poliklinik tempat resep dikeluarkan juga berbeda antara kedua kelompok; sebagai contoh adalah resep yang berasal dari poliklinik kardiovaskular; proporsi pasien yang menerima resep polifarmasi lebih besar dibanding dengan yang tidak menerima resep polifarmasi $(72,1 \%$ vs $33,1 \%$; $\mathrm{p}<0,001)$ (Tabel 2). Dapat disimpulkan, usia, jenis kelamin, status asuransi, dan asal poliklinik merupakan determinan peresepan polifarmasi di RS rujukan tersebut.

Tabel 3 memperlihatkan rasio prevalensi (RP) determinan masing-masing. Berdasarkan atas analisis multivariat terhadap determinan tersebut, didapatkan bahwa determinan yang paling besar rasio prevalensinya adalah poliklinik kardiovaskular (RP:8,80; IK95\%: 6,35-12,19). Determinan lain dengan risiko polifarmasi $>3$

Tabel 2 Perbedaan Usia, Jenis kelamin, Status Asuransi, dan Asal Poliklinik antara Peresepan Polifarmasi dan Tidak Polifarmasi

\begin{tabular}{|c|c|c|c|c|c|c|c|}
\hline \multirow{2}{*}{ Variabel } & \multicolumn{6}{|c|}{ Peresepan dengan Polifarmasi } & \multirow{2}{*}{ Nilai p* } \\
\hline & Ya & $\mathbf{n}$ & $\%$ & Tidak & $\mathbf{n}$ & \% & \\
\hline \multicolumn{8}{|l|}{ Usia (tahun) } \\
\hline$<60$ & & 328 & 40,2 & & 956 & 55,2 & \multirow[t]{2}{*}{$<0,001$} \\
\hline$\geq 60$ & & 488 & 59,8 & & 776 & 44,8 & \\
\hline \multicolumn{8}{|l|}{ Jenis kelamin } \\
\hline Perempuan & & 350 & 42,9 & & 960 & 55,4 & \multirow{2}{*}{$<0,001$} \\
\hline Laki-laki & & 466 & 57,1 & & 772 & 44,6 & \\
\hline \multicolumn{8}{|l|}{ Status asuransi } \\
\hline Askes & & 601 & 73,6 & & 972 & 50,1 & \multirow{5}{*}{$<0,001$} \\
\hline Jamkesmas & & 100 & 12,3 & & 310 & 17,9 & \\
\hline Gakinda & & 86 & 10,5 & & 207 & 15,4 & \\
\hline Umum & & 13 & 1,6 & & 131 & 7,6 & \\
\hline Lain-lain & & 16 & 2,0 & & 52 & 3,0 & \\
\hline \multicolumn{8}{|l|}{ Asal poliklinik } \\
\hline Kardiovaskular & & 588 & 72,1 & & 575 & 33,1 & \multirow{5}{*}{$<0,001$} \\
\hline Saraf & & 64 & 7,8 & & 474 & 27,4 & \\
\hline Ginjal hipertensi & & 46 & 5,6 & & 396 & 22,9 & \\
\hline Geriatri & & 90 & 11,1 & & 116 & 6,7 & \\
\hline Paru & & 28 & 3,4 & & 171 & 9,9 & \\
\hline Jumlah & & 816 & 100 & & 1.732 & 100 & \\
\hline
\end{tabular}

Uji statistik: chi-square; lain-lain: Jamsostek, kontraktor 
kali adalah poliklinik geriatri (RP:6,68; IK95\%: 4,43-10,08) dan juga Askes (RP:6,23; IK95\%: 3,49-11,12; Tabel 3, 4).

Terdapat 574 orang pasien yang berobat ke lebih dari satu poliklinik sehingga mendapatkan beberapa resep pada hariyang sama. Karakteristik resep yang berasal dari beberapa poliklinik ini adalah resep lebih banyak berasal dari pasien dengan usia $\geq 60$ tahun $(57,1 \%)$, perempuan (6o,6\%), dan pasien Askes (77,4\%). Polifarmasi pada resep gabungan ini adalah 59,8\% (343 orang). Karakteristik pasien penerima resep lebih banyak berusia $\geq 60$ tahun $(60,9 \%$ vs $39,1 \%$; p<0,05), perempuan $(57,4 \%$ vs $42,6 \%$; $\mathrm{p}<0,05)$, menggunakan Askes (82,5\% vs 17,5\%; p>0,05) (Tabel 5). Asal poliklinik yang terbanyak adalah gabungan poliklinik ginjal hipertensi dan poliklinik endokrin (11,9\%). Sebanyak 27,9\% poliklinik gabungan ini melibatkan poliklinik endokrin. Jumlah jenis obat resep gabungan tersebut dapat mencapai hingga 12 jenis obat untuk setiap pasien.

Tabel 3 Hubungan Kelompok Usia, Jenis Kelamin, Status Asuransi, dan Asal Poliklinik dengan Peresepan Polifarmasi

\begin{tabular}{|c|c|c|c|c|c|c|c|c|c|}
\hline \multirow{2}{*}{ Variabel } & \multicolumn{6}{|c|}{ Peresepan Polifarmasi } & \multirow{2}{*}{$\mathbf{R P}$} & \multirow{2}{*}{ IK 95\% } & \multirow{2}{*}{$\begin{array}{c}\text { Nilai } \\
\mathbf{p}^{*}\end{array}$} \\
\hline & Ya & $\mathbf{n}$ & $\%$ & Tidak & $\mathbf{n}$ & $\%$ & & & \\
\hline \multicolumn{10}{|l|}{ Usia (tahun) } \\
\hline$<60$ & & 328 & 40,2 & & 956 & 55,2 & 1 & $1,55^{-2,17}$ & $<0,001$ \\
\hline$\geq 60$ & & 488 & 59,8 & & 776 & 44,8 & 1,83 & & \\
\hline \multicolumn{10}{|l|}{ Jenis kelamin } \\
\hline Perempuan & & 350 & 42,9 & & 960 & 5,4 & 1 & & \\
\hline Laki-laki & & 466 & 57,1 & & 772 & 44,6 & 1,66 & $1,40-1,96$ & $<0,001$ \\
\hline \multicolumn{10}{|l|}{ Status asuransi } \\
\hline Askes & & 601 & 73,6 & & 972 & 56,1 & 6,23 & $3,49-11,12$ & \\
\hline Jamkesmas & & 100 & 12,3 & & 310 & 17,9 & 3,25 & $1,76-6,00$ & $<0,001$ \\
\hline Gakinda & & 86 & 10,5 & & 267 & 15,4 & 3,25 & $1,75^{-6,03}$ & \\
\hline Umum & & 13 & 1,6 & & 131 & 7,6 & 1 & & \\
\hline Lain-lain & & 16 & 2,0 & & 52 & 3,0 & 3,10 & $1,39-6,89$ & \\
\hline \multicolumn{10}{|l|}{ Asal poliklinik } \\
\hline Kardiovaskular & & 588 & 72,1 & & 575 & 33,1 & 8,80 & $6,35^{-12,19}$ & \\
\hline Saraf & & 64 & 7,8 & & 474 & 27,4 & 1,16 & $0,78-1,74$ & $<0,001$ \\
\hline Ginjal hipertensi & & 46 & 5,6 & & 396 & 22,9 & 1 & & \\
\hline Geriatri & & 90 & 11,1 & & 116 & 6,7 & 6,68 & $4,43-10,08$ & \\
\hline Paru & & 28 & 3,4 & & 171 & 9,9 & 1,41 & $0,85^{-2,33}$ & \\
\hline Jumlah & & 816 & 100 & & .732 & 100 & & & \\
\hline
\end{tabular}

*uji chi-square, RP: rasio prevalensi, IK: interval kepercayaan, lain-lain: Jamsostek, kontraktor

Tabel 4 Hasil Analisis Multivariat Regresi Logistik

\begin{tabular}{|c|c|c|c|c|c|c|}
\hline \multirow{2}{*}{ Variabel } & \multirow[t]{2}{*}{ Koefisien } & \multirow[t]{2}{*}{ S.E } & \multirow[t]{2}{*}{ Nilai p } & \multirow[t]{2}{*}{$\mathbf{R P}$} & \multicolumn{2}{|c|}{ IK95\% } \\
\hline & & & & & Min & Maks \\
\hline Laki-laki & 0,444 & 0,095 & 0,001 & 1,558 & 1,293 & 1,878 \\
\hline Askes & 1,176 & 0,313 & 0,001 & 3,242 & 1,754 & 5,994 \\
\hline Jamkesmas & 0,742 & 0,331 & 0,025 & 2,099 & 1,097 & 4,016 \\
\hline Gakinda & 0,683 & 0,335 & 0,041 & 1,981 & 1,027 & 3,819 \\
\hline Lain-lain & 0,902 & 0,438 & 0,040 & 2,464 & 1,044 & 5,818 \\
\hline Poliklinik kardiovaskular & 2,154 & 0,168 & 0,001 & 8,622 & 6,204 & 11,981 \\
\hline Poliklinik geriatrik & 1,808 & 0,213 & 0,001 & 6,099 & 4,017 & 9,261 \\
\hline Poliklinik saraf & 0,299 & 0,208 & 0,152 & 1,348 & 0,896 & 2,028 \\
\hline Poliklinik paru & 0,458 & 0,260 & 0,079 & 1,580 & 0,949 & 2,633 \\
\hline
\end{tabular}

Ket: RP: rasio prevalensi, IK: interval kepercayaan, lain-lain: Jamkesmas, kontraktor 
Tabel 5 Perbedaan Usia, Jenis kelamin, dan Status Asuransi antara Peresepan Polifarmasi dan Tidak Polifarmasi pada Resep Gabungan

\begin{tabular}{|c|c|c|c|c|c|c|c|}
\hline \multirow{2}{*}{ Variabel } & \multicolumn{6}{|c|}{ Peresepan dengan Polifarmasi } & \multirow{2}{*}{ Nilai p* } \\
\hline & Ya & $\mathbf{n}$ & $\%$ & Tidak & $\mathbf{n}$ & $\%$ & \\
\hline $\begin{array}{l}\text { Usia (tahun) } \\
\quad<60 \\
\geq 60\end{array}$ & & $\begin{array}{l}134 \\
209\end{array}$ & $\begin{array}{c}39,1 \\
60,9\end{array}$ & & $\begin{array}{l}112 \\
119\end{array}$ & $\begin{array}{r}48,5 \\
51,5\end{array}$ & 0,016 \\
\hline $\begin{array}{l}\text { Jenis kelamin } \\
\text { Perempuan } \\
\text { Laki-laki }\end{array}$ & & $\begin{array}{c}197 \\
146\end{array}$ & $\begin{array}{l}57,4 \\
42,6\end{array}$ & & $\begin{array}{c}151 \\
80\end{array}$ & $\begin{array}{l}65,4 \\
34,6\end{array}$ & 0,034 \\
\hline $\begin{array}{l}\text { Status asuransi } \\
\text { Askes } \\
\text { Jamkesmas } \\
\text { Gakinda } \\
\text { Umum } \\
\text { Lain-lain } \\
\end{array}$ & & $\begin{array}{r}283 \\
34 \\
20 \\
2 \\
4 \\
\end{array}$ & $\begin{array}{r}82,5 \\
9,9 \\
5,8 \\
0,6 \\
1,2 \\
\end{array}$ & & $\begin{array}{r}161 \\
36 \\
22 \\
4 \\
8 \\
\end{array}$ & $\begin{array}{r}69,7 \\
15,6 \\
9,5 \\
1,7 \\
3,5 \\
\end{array}$ & 0,006 \\
\hline Jumlah & & 343 & 100 & & 231 & 100 & \\
\hline
\end{tabular}

\section{Pembahasan}

Hasil yang diperoleh bahwa prevalensi resep dengan polifarmasi cukup tinggi, satu pertiga resep yang berasal dari poliklinik kardiovaskular, poliklinik geriatri, poliklinik ginjal hipertensi, poliklinik saraf, dan poliklinik paru adalah resep dengan polifarmasi. Jumlah jenis obat dalam tiap resepnya berkisar antara 5 sampai 11 jenis obat. Resep dengan polifarmasi ini lebih banyak berasal dari pasien usia tua, laki-laki, pengguna Askes, dan berasal dari poliklinik kardiovaskular.

Penelitian yang telah dilaksanakan di luar negeri mengenai polifarmasi memperlihatkan prevalensi polifarmasi yang lebih besar. Namun, penelitian ini dilakukan pada pasien atau rekam medis yang berasal dari ruang rawat inap, dokter keluarga, dan komunitas, sementara penelitian ini mengambil sampel penelitian yang berasal dari poliklinik rawat jalan di RS rujukan yang sekaligus RS pendidikan..$^{3-5,9,10}$ Suatu systematic review menunjukkan bahwa angka prevalensi polifarmasi di layanan kesehatan primer berkisar 27-59\% dan 46-84\% pada layanan kesehatan rumah sakit (RS). ${ }^{11}$ Cukup tingginya prevalensi polifarmasi ini dapat disebabkan oleh beberapa penyebab, di antaranya rekomendasi/pedoman penatalaksanaan yang telah merekomendasikan penggunaan beberapa jenis obat untuk suatu penyakit. Penelitian di Swedia memperlihatkan bahwa terdapat pedoman klinik baru, sebelum pedoman klinik tersebut diperkenalkan secara resmi, pedoman klinik tersebut dikenal hanya dalam bentuk pendahuluan. Konsekuensinya, pedoman ini dapat memengaruhi pola pemberian resep dan berkembangnya polifarmasi. Banyak pula obat yang dipergunakan untuk pencegahan sehinggaakanberpotensimemperbesarprevalensi polifarmasi.4,12 Pedoman klinis penatalaksanaan penyakit dianggap sebagai "medicine generators" yang cenderung menambahkan suatu obat sehingga menyebabkan penggunaan obat yang multipel. ${ }^{12-14}$ Selain itu, terdapat satu masalah penting bahwa pasien lanjut usia dengan kondisi kronik yang multipel, mempunyai kebutuhan klinis yang berbeda dibanding dengan pasien usia yang lebih muda dengan kondisi kronik tunggal yang telah menjadi dasar bagi pedoman penatalaksanaan klinis. ${ }^{15}$

Sebagai RS rujukan menyebabkan kondisi RS menerima pasien-pasien dalam jumlah yang besar, dengan kondisi yang berat, atau dengan penyakit kronik seperti penyakit kardiovaskular. Kebanyakan RS rujukan itu juga merupakan RS pendidikan yang terdapat peserta didik yang sedang mengambil spesialisasi. Mereka bertugas di poliklinik rawat jalan di bawah supervisi oleh konsulen. Mereka adalah pemberi resep pada penelitan ini. Mereka bertugas dengan rotasi waktu tertentu, artinya pelayanan di poliklinik rawat jalan dilakukan oleh peserta didik yang berbeda-beda berdasarkan atas jadwal rotasinya, akan mengakibatkan pasien yang berobat ke poliklinik rawat jalan itu dapat ditangani oleh dokter yang berbeda tiap kunjungannya sehingga dapat menjadi penyebab tingginya polifarmasi ini. Namun, pada penelitian ini tidak dilakukan penelitian terhadap pemberi resep.

Kedua kondisi ini juga dapat menyebabkan keterbatasan waktu yang dimiliki oleh seorang dokter untuk dapat melaksanakan pelayanan di poliklinik rawat jalan sehingga dapat menjadi 
penyebab polifarmasi yang tinggi. Kurangnya komunikasi antara dokter umum dan spesialis di rumah sakit (RS) mengenai pengobatan pasien akan menurunkan kualitas pengobatan. ${ }^{13}$ Banyak klinisi yang tidak meminta pasiennya mencatat atau menyusun secara lengkap daftar obat yang dimiliki atau dikonsumsinya (termasuk obatobat yang dibeli sendiri) dan tidak melihat daftar obat pasien secara reguler guna mengevaluasi obat-obat yang dapat dihentikan. ${ }^{12,16}$ Pengaruh tekanan dari pasien juga dapat menjadi faktor yang berkontribusi terhadap berkembangnya penggunaan obat yang multipel. ${ }^{13}$

Keterbatasan waktu yang dimiliki oleh klinisi dalam melaksanakan pelayanan dipoliklinikrawat jalan juga dapat mengakibatkan pengulangan resep yang kemudian berpotensi untuk terjadi polifarmasi. Terdapat proporsi yang signifikan antara populasi yang menerima resep ulangan dan proporsinya meningkat yang seiring dengan usia. ${ }^{16,17}$ Keterbatasan waktu penelitian juga dapat menyebabkan kurang baiknya hubungan antara pasien dan klinisi sehingga dapat memengaruhi perilaku pasien atau dokter dalam menggunakan obat. ${ }^{18}$

Prevalensi resep dengan polifarmasi lebih banyak berasal dari pasien berusia $\geq 60$ tahun. Enam dari sepuluh pasien yang berusia $\geq 60$ tahun telah menerima resep dengan polifarmasi. Kemungkinan pasien usia $\geq 60$ tahun menerima resep dengan polifarmasi 1,83 kali lebih besar bila dibanding dengan pasien usia $<60$ tahun. Median usia pasien secara bermakna lebih tua dibanding dengan pasien yang mendapatkan resep yang tidak polifarmasi. Namun, walaupun terdapat perbedaan yang signifikan dan terdapat hubungan antara resep polifarmasi dan usia, setelah dikontrol dengan faktor jenis kelamin, status asuransi, dan asal klinik, faktor usia ini menjadi tidak signifikan.

Penelitian yang dilaksanakan di luar negeri memperlihatkan bahwa $2 / 3$ pasien usia $\geq 70$ tahun merupakan pengguna obat-obatan polifarmasi. Prevalensi polifarmasi akan meningkat seiring dengan usia. ${ }^{19}$ Bila dibanding dengan faktor jenis kelamin, pendapatan dan pendidikan, faktor usia ini menunjukkan hasil yang tidak signifikan. ${ }^{9}$ Sama halnya pada penelitian ini, faktor usia menunjukkan hasil yang tidak signifikan setelah dikontrol oleh jenis kelamin, status asuransi, dan asal poliklinik.

Polifarmasi lebih banyak diterima oleh pasien usia tua dengan beberapa kemungkinan alasan. Jumlah penyakit rata-rata yang diderita oleh pasien lanjut usia akan semakin meningkat yang ternyata menyebabkan pula peningkatan dalam penggunaan obat-obatan jangka panjang. ${ }^{3}$ Banyak kondisi kronik seperti strok, penyakit kardiovaskular, gangguan muskuloskeletal, dan demensia yang sangat berhubungan erat dengan faktor usia dapat juga meningkatkan polifarmasi. Implementasi pedoman dalam penatalaksanaan pencegahan sekunder atau peningkatan taraf penatalaksanaan untuk tekanan darah, diabetes melitus, lemak darah, dan osteoporosis dapat meningkatkan polifarmasi. ${ }^{11}$

Resep keseluruhannya lebih banyak berasal dari pasien perempuan. Beberapa penelitian menunjukkan bahwa pada kelompok usia $<80$ tahun perempuan lebih banyak menggunakan obat karena perempuan lebih memerhatikan kesehatan dan mengkonsultasikan kesehatannya ke pelayanan kesehatan lebih sering dan lebih awal dibanding dengan laki-laki, lebih terbiasa mengonsumsi obat, dan lebih mudah mengenali atau juga merasakan masalah kesehatannya. ${ }^{10}$ Pasien perempuan ternyata juga lebih banyak mengunjungi fasilitas kesehatan dikarenakan penyakit kronik yang dialami dan health-related quality oflife (HRQL). ${ }^{20}$ Sikap pemberi resep yang cenderung mengobati keluhan-keluhan ringan dan juga memenuhi keinginan pasien pun dapat menyebabkan tingginya penggunaan obat pada perempuan. ${ }^{21}$ Sementara pada kelompok usia $>80$ tahun laki-laki lebih banyak menggunakan obat dibanding dengan perempuan. Hal ini dapat dikarenakan laki-laki secara umum lebih lambat mengunjungi fasilitas kesehatan bila dibanding dengan pasien perempuan, yaitu setelah proses penyakitnya sudah mulai atau ketika gejalagejala sudah mulai muncul. ${ }^{10}$

Namun, meskipun karakteristik pasien yang menerima resep pada penelitian ini lebih banyak perempuan, proporsi polifarmasi sendiri lebih banyak pada resep yang diterima pasien lakilaki. Hasil ini sejalan dengan penelitian di luar negeri yang menunjukkan bahwa peningkatan prevalensi polifarmasi pada laki-laki 2 kali lebih besar daripada perempuan. ${ }^{4}$ Perlu penelitian lebih lanjut untuk mencari kemungkinan penyebab proporsi polifarmasi pada pasien laki-laki di RS ini lebih besar daripada perempuan. Namun, terdapat beberapa keadaan yang dapat menjadi kemungkinan penyebab, di antaranya adalah prevalensi beberapa penyakit kronik seperti diabetes melitus, penyakit paru obstruktif kronik, strok, gagal ginjal kronik lebih tinggi pada lakilaki dibanding dengan perempuan yang sekaligus juga berhubungan dengan kebiasaan merokok yang lebih tinggi pada laki-laki dibanding dengan perempuan. Aktivitas fisik pada laki-laki lebih rendah dibanding dengan perempuan. Prevalensi hipertensi, penyakit jantung koroner, dan juga asma pada laki-laki tidak berbeda jauh dengan perempuan. ${ }^{22-24}$

Resep-resep dengan polifarmasi lebih banyak 
diterima oleh pasien yang menggunakan Askes. Di satu sisi tujuan dari Sistem Jaminan Sosial Nasional adalah untuk memberikan jaminan terpenuhinya kebutuhan dasar kehidupan yang layak bagi setiap peserta. Sementara itu, di sisi lainnya Badan Penyelenggara Jaminan Sosial mengembangkan sistem pelayanan kesehatan, sistem kendali mutu pelayanan, dan juga sistem pembayaran pelayanan kesehatan yang bertujuan meningkatkan efisiensi dan efektivitas. ${ }^{25}$ Resep obat yang di-cover oleh asuransi secara signifikan meningkatkan obat yang diresepkan. ${ }^{26}$

Besarnya kemungkinan pasien yang berobat ke poliklinik kardiovaskular mendapatkan resep dengan polifarmasi pada penelitian ini adalah 8,8 o kali lebih besar bila dibanding dengan pasien yang berobat ke poliklinik ginjal hipertensi. Resep yang berasal dari poliklinik kardiovaskular ini juga 8,62 kali lebih besar kemungkinannya merupakan resep dengan polifarmasi dibanding dengan poliklinik ginjal hipertensi dan setelah dikontrol faktor jenis kelamin dan status asuransi.

Besarnya kemungkinan pasien menerima resep polifarmasi dari poliklinik kardiovaskular lebih besar dibanding dengan klinik lainnya dapat disebabkan beberapa faktor. Insidensi penyakit hipertensi dan fibrilasi atrial berhubungan erat dengan peningkatan polifarmasi itu. ${ }^{3}$ Hubungan antara polifarmasi dan peningkatan penggunaan obat-obatan kardiovaskular tersebut dan diabetes melitus pada lanjut usia dapat mengindikasikan bahwa paparan terhadap penggunaan obat yang multipel secara umum berhubungan dengan penatalaksanaan jangka panjang penyakit yang kronik. ${ }^{9}$ Obat kardiovaskular dan analgetik adalah obat yang sering terdapat dalam polifarmasi pada lanjut usia dengan risiko empat kali lebih tinggi dibanding dengan obat lain.19,27

Fakta bahwa kemungkinan pasien menerima resep polifarmasi dari poliklinik kardiovaskular pada penelitian ini paling besar bila dibanding dengan klinik lainnya, bahkan setelah dikontrol oleh karakteristik jenis kelamin serta status asuransi pasien mengharuskan klinisi dan pihakpihak yang bertanggung jawab terhadap jaminan mutu pelayanankesehatan memberikan perhatian yang lebih dan melakukan evaluasi secara intensif terhadap resep yang diberikannya, khususnya pada pasien usia lanjut dan yang memerlukan obat untuk penyakit kardiovaskular. ${ }^{19,28}$

Jumlah jenis obat yang terdapat pada resep polifarmasi ini bervariasi hingga mencapai 11 jenis obat per resep. Bilamana diklasifikasikan ke dalam kategori polifarmasi minor, moderat, dan mayor, polifarmasi pada penelitian ini termasuk kategori mayor ( $>5$ jenis obat). ${ }^{3}$ Jumlah jenis obat ini dapat saja lebih tinggi karena pasien biasanya tidaklah menganggap beberapa agen sebagai obat, seperti pada terapi obesitas, alergi, nyeri, diare, gangguan ginjal dan kandung kemih, gangguan saluran pencernaan, serta suplemen vitamin maupun mineral. ${ }^{9}$ Penelitian ini pun tidak melakukan recall terhadap obat-obat yang masih dikonsumsi pasien ketika menerima resep ini dan obat OTC yang dibeli dan dikonsumsi sendiri oleh pasien.

Polifarmasi itu sulit untuk dihindari karena dipengaruhi pula oleh kondisi dan diagnosis pasien. Namun, orang-orang yang terlibat dalam pemberian resep misalnya dokter dan bagian farmasi tetap perlu selalu memperhatikan potensi interaksi obat dan efek samping obat, serta memperhitungkan juga mengenai pengaruhnya terhadap cost effectiveness. Klinisi dan pihakpihak yang juga terkait dan bertanggung jawab dalam penjaminan mutu pelayanan kesehatan di RS harus melakukan usaha untuk mengurangi masalah yang berhubungan dengan polifarmasi, khususnya terhadap kelompok yang berisiko tinggi mendapatkan resep dengan polifarmasi seperti pasien usia lanjut yang sedang menerima pengobatan penyakit kardiovaskular. Di samping usia, jenis kelamin, status asuransi, dan asal poliklinik, faktor yang juga akan menentukan tinggi rendahnya polifarmasi adalah para klinisi sebagai pemberi resep itu. Selain karakteristik pasien penerima resep yang dianalisis dalam penelitian ini, diperlukan penelitian lebih lanjut untuk mengetahui penyebab lain seorang dokter memberikan resep polifarmasi.

Penelitian ini juga mendapatkan temuan tambahan yang harus diberikan perhatian, yaitu resep gabungan dari beberapa resep yang berasal dari poliklinik berbeda yang diterima oleh seorang pasien dalam 1 (satu) hari yang sama. Prevalensi polifarmasi pada resep gabungan lebih besar dibandingkan dengan resep tunggal, yaitu 6 dari 10 pasien yang menerima beberapa resep dalam satu hari yang sama mendapatkan polifarmasi bila obat-obatan dalam resep-resep tersebut digabungkan. Jumlah jenis obat yang diterima pasien pun akan lebih banyak, dapat mencapai 12 jenis obat. Oleh karena itu, temuan tambahan ini penting sekali untuk diperhatikan.

Hal ini dapat disebabkan oleh kurangnya komunikasi antarpemberi resep yang disebabkan oleh masih menggunakan resep manual dan keterbatasan waktu, atau dapat juga disebabkan oleh pengetahuan mengenai kombinasi obatobatan yang dapat berinteraksi masih kurang. Transfer informasi obat-obatan yang digunakan oleh pasien tidaklah optimal. ${ }^{29}$ Pasien dengan penyakit kronik misalnya pada diabetes melitus sering menemui beberapa orang dokter spesialis dan terdapat suatu kecenderungan yang kuat untuk menambahkan obat dibandingkan dengan 
menghentikan obat tersebut. Banyak pasien akan berasumsi bahwa para pemberi resep tersebut saling berkomunikasi satu dengan yang lainnya dan menyadari apa yang diresepkan oleh masingmasing. Penambahan suatu jenis obat yang terus menerus tanpa evaluasi yang periodik terhadap regimen obat ini merupakan kontributor utama berkembangnya polifarmasi. ${ }^{10}$ Pasien juga dapat berasumsi bahwa data komputer dari farmasi yang berbeda saling berhubungan dan dapat mengidentifikasi potensi interaksi antarobat. ${ }^{13}$

Jumlah obat yang diresepkan meningkat seiring dengan jumlahnya dokter yang ditemui. Semakin banyak jumlah klinisi yang memberi resep kepada satu orang pasien, akan semakin besar risiko pasien mendapat kombinasi obat yang tidak tepat. Meminimalisir jumlah dokter yang dikunjungi oleh pasien diharapkan dapat menurunkan insidensi polifarmasi. ${ }^{16,30}$

Hal ini juga dapat terjadi karena kurangnya komunikasi antara pemberi resep, penulisan resep yang manual dengan mempergunakan kertas, tidak ada cek ulang dari farmasi, serta belum mempergunakan resep elektronik yang terhubung antarpoliklinik dan farmasi. Resepresep gabungan yang menyebabkan polifarmasi tersebut paling banyak adalah resep yang berasal dari poliklinik ginjal hipertensi dan endokrin. Hampir sepertiganya resep gabungan ini juga melibatkan poliklinik endokrin, seperti gabungan antara poliklinik kardiovaskular dan endokrin, poliklinik saraf dan endokrin.

Kondisi ini dapat disebabkan faktor-faktor yang berkontribusi terhadap polifarmasi pada pasien diabetes melitus, misalnya diperlukannya kadar gula darah yang terkontrol secara ketat, komorbiditas yang juga sering terjadi menyertai diabetes melitus yang juga membutuhkan terapi obat multipel misalnya hipertensi, dislipidemia, coronary artery disease, neuropati, congestive heart failure, dan renal disease. ${ }^{31}$

\section{Simpulan}

Prevalensi peresepan polifarmasi di RS rujukan dan sekaligus juga RS pendidikan cukup tinggi, terlebih jika seorang pasien menerima beberapa resep dalam satu hari yang sama. Determinan peresapan polifarmasi yang paling dominan adalah resep-resep dari poliklinik kardiovaskular, poliklinik geriatri, dan peserta Askes. Diperlukan pengawasan ketat terhadap potensi interaksi obat dan efek samping obat, khususnya obatobatan kardiovaskular. Beberapa tantangan bagi klinisi maupun farmasi yang harus dilakukan di antaranya meningkatkan penggunaan obat yang rasional, serta edukasi terhadap pasien, klinisi, maupun farmasi.

\section{Ucapan Terima Kasih}

Terima kasih disampaikan kepada semua pihak yang sudah membantu sehingga penelitian ini berjalan dengan lancar.

\section{Daftar Pustaka}

1. Bushardt RL, Massey EB, Simpson TW, Ariail JC, Simpson KN. Polypharmacy: misleading, but manageable. Clin Interventions Aging. 2008;3(2):383-9.

2. Souza PM, Neto LL, Kusano LTE, Pereira MG. Diagnosis and control of polypharmacy in the elderly. Rev Saude Publica. 2007; 41(6):1049-53.

3. Viktil KK, Blix HS, Moger TA, Reikvam A. Polypharmacy as commonly defined is an indicator of limited value in the assessment of drug-related problems. Br J Clin Pharmacol. 2006;63(2):187-95.

4. Kuijpers MAJ, Marum RJ, Egberts ACG, Jansen PAF. Relationship between polypharmacy and underprescribing. $\mathrm{Br} \mathrm{J}$ Clin Pharmacol. 2007;65(1):130-3.

5. Hajjar ER, Cafiero AC, Hanlon JT. Polypharmacy in elderly patients. Am J Geriatric Pharmacother. 2007;5(4):345-51.

6. Hovstadius B, Hovstadius K, Astrand B, Petersson G. Increasing polypharmacyan individual-based study of the Swedish population 2005-2008. BMC Clin Pharmacol. 2010;10:16.

7. KohY, Kutty FM,LiSC. Drug-related problems in hospitalized patients on polypharmacy: the influence of age and gender. Ther Clin Risk Management. 2005;1(1):39-48.

8. PERMENKES RI No. 001 Tahun 2012 tentang Sistem Rujukan Pelayanan Kesehatan Perorangan.

9. Flores LM, Mengue SS. Drug use by the elderly in Southern Brazil. Rev Saude Publica. 2005;39(6):2-5.

10. Venturini CD, Engroff P, Ely LS, Zago LFA, Schoeter G, Gomes I, dkk. Gender differences, polypharmacy, and potential pharmacological interactions in the elderly. Clinics. 2011;66(11):1867-72.

11. Elmstahl S, Linder H. Polypharmacy and inappropriate drug use among older peoplea Systematic review. Healthy Aging Clin Care Elderly. 2013;5:1-8.

12. Anthierens S, Tansens A, Petrovic M, Christiaens T. Qualitative insights into general practitioners views on polypharmacy. BMC Fam Practice. 2010;11(65):2-5.

13. Moen J, Norrgard S, Antonov K, Nilsson JLG, Ring L. GP's perceptions of multiple- 
medicine use in older patients. Journal of Evaluation in Clinical Practice ISSN. Inter $J$ Public Health Policy Health Services Research. 2010;6:69-75.

14. Tinetti ME, Bogardus ST, Agustini JV. Potential pitfalls of disease-specific guidelines for patients with multiple conditions. N Engl J Med. 2004;351:27.

15. Mc Murdo MET, Witham MD, Gillespie ND. Including older people in clinical research. $\mathrm{Br}$ Med J. 2005;331:1036-7.

16. Rollason V, Vogt N. Reduction of polypharmacy in the elderly. A systematic review of the rule of the pharmacist. Drugs Aging. 2003;20(11):817-32.

17. Petty DR, Zermansky AG, Alldred DP. The scale of repeat prescribing time for an update. BMC Health Services Research. 2014;14:76.

18. Moen J, Bohm A, Tillenius T, Antonov K, Nilsson JLG, Ring L. I don't know how many of these (medicine) are necessary- a focus group study among elderly users of multiple medicines. Patient Education Counseling. 2009;74:135-41.

19. Bjerrum L, Sogaard J, Hallas J, Kragstrup J. Polypharmacy: correlation with sex, age and drug regimen; a prescription database study. Eur J Clin Pharmacol. 1998;54:197-202.

20. Redondo A, Castillon PA, Banegas JR, Artalejo FR. Gender differences in the utilization of health-care services among the older adult population of Spain. BMC Public Health. 2006;6:155.

21. Kennerfalk A, Ruigomez A, Wallander MA, Wilhemsen L, Johansson S. Geriatric drug therapy and healthcare utilization in the United Kingdom. Ann Pharmacother. 2002;36.

22. Soewondo P, Pramono LA. Prevalence, characteristics, and predictors of prediabetes in Indonesia. Med $\mathrm{J}$ Indones. 2011;20(4):283.

23. Action on Smoking and Health fact at Glance. Smoking statistics.2015 (diunduh Januari 2016). Tersedia dari: http://www.ash.org. uk/files/documents/ASH_93.pdf

24. Kemenkes RI. Riset Kesehatan Dasar: Penyakit tidak menular. Jakarta: Badan Penelitian dan Pengembangan Kesehatan Kementrian Kesehatan RI; 2013.

25. UURI No 40 Tahun 2004. Sistem Jaminan Sosial Nasional.

26. Khan N, Kaestner R, Lin SJ. Prescription drug insurance and its effect on utilization and health of the elderly. NBER Working Paper. Nat Bureau Economic Research. 2007;12848:24-5.

27. Linjakumpu T, Hartikainen S, Klaukka T, Veijola J, Kivela SL, Isoaho R. Use of medications and polypharmacy are increasing among the elderly. J Clin Epidemiol. 2002;55:809-17.

28. Fulton MM, Alen ER. Polypharmacy in the elderly: a literature review. J Am Academy Nurse Practitioners. 2005;17(4):123-32.

29. Viktil KK, Blix HS, Reikvam A. The Janus face of polypharmacy- overuse versus underuse of medication. Norsk Epidemiol. 2008;18(2): $147-52$.

30. Tamblyn RM, Mc Leod PJ, Abrahamowicz M. Do too many cooks spoil the broth? Multiple physician involvement in medical management in the elderly patients and potentially inappropriate drug combinations. CMAJ. 1996;154:1177-84.

31. Good CB. Polypharmacy in elderly patients with diabetes. Diabetes Spectrum. 2002;15(4):240-8. 